\title{
SIGNIFICANCE OF ANALYSIS OF LIPID EXTRACTS IN CERVICAL CANAL SECRETION FOR DIAGNOSING OF PLACENTA-ASSOCIATED COMPLICATIONS OF PREGNANCY
}

Lomova NA $\otimes$, Chagovets W, Tokareva AO, Dolgopolova EL, Karapetyan TE, Magomedova AP, Shmakov RG

Kulakov National Medical Research Center for Obstetrics, Gynecology and Perinatology, Moscow, Russia

Omics technologies hold great potential as the basis for development of the new diagnostic approaches in obstetrics. Cervicovaginal fluid (CVF) as part of the mother-placenta-fetus system can be used to diagnose obstetric complications. This study aimed to identify the features of lipid composition of the cervical canal secretion peculiar to Intrauterine Growth Restriction (IUGR) and preeclampsia (PE). We took CVF samples from 57 pregnant women and subjected them to an in-depth clinical-anamnestic and mass-spectrometric analysis. Lipid extracts of CVF were analyzed with a liquid chromatography system coupled with a mass analyzer. As a result, we identified 239 lipid compounds. In case of 17 lipids, mathematical analysis revealed significant differences between samples from women with normal pregnancy indicator values (normal group) and patients from the IUGR group $(p<0.05)$. As for the normal group and PE group patients, there were significant differences identified for 3 lipids $(p<0.05)$. Comparison of samples from the PE and IUGR groups yielded statistically significant differences in levels of two lipids $(p<0.05)$. Mainly, the lipids were oxylipins, sphingomyelins, triglycerides, and cardiolipins. The developed diagnostic model had the sensitivity of 0.81 and specificity of 0.91 (cut-off level - 0.50; AUC - 0.85). The data obtained are valuable in the context of development of the new methods of diagnosing placentaassociated complications of pregnancy and for understanding new mechanisms of pathogenesis of these complications.

Keywords: prodnostic value, non-invasive diagnostics, preeclampsia, intrauterine growth restriction, lipidomics

Funding: the study was supported through the state assignment of the Ministry of Health of the Russian Federation [State registration number AAAA-A18-118053190026-6]. Acknowledgements: the authors are grateful to Dr. V. E. Frankevich, Head of the Department of Systems Biology in Reproduction of the V. I. Kulakov National Medical Research Center for Obstetrics, Gynecology and Perinatology, for his help in organization of the study, systematic analysis and manuscript editing.

Author contribution: Lomova NA — analysis of clinical data, systematic analysis, manuscript authoring; Chagovets W - metabolic analysis (mass spectrometry), statistical analysis of the data obtained, manuscript editing; Tokareva AO - metabolic analysis (mass spectrometry), mass spectrometry data processing Dolgopolova EL — collection and preparation of biological fluids, statistical analysis of the results; Karapetyan TE — analysis of clinical data, statistical analysis of the results; Magomedova AP — collection and preparation of biological fluids; Shmakov RG — analysis of clinical data, systematic analysis, manuscript editing.

Compliance with ethical standards: the study was approved by the ethical committee of Kulakov National Medical Research Center for Obstetrics, Gynecology and Perinatology (Minutes \#11 of November 11, 2021), conducted in accordance with the requirements of the Declaration of Helsinki, International Conference on Harmonization (ICH), Standards of Good Clinical Practice (GCP), Federal Law "On the Basics of Health Protection of Citizens in the Russian Federation"; all patients signed a voluntary informed consent to participate in the study.

$\triangle$ Correspondence should be addressed: Natalya A. Lomova

Akademika Oparina, 4, Moscow, 117997, Russia; natasha-lomova@yandex.ru

Received: 23.11.2021 Accepted: 20.12.2021 Published online: 29.12.2021

DOI: $10.24075 /$ brsmu.2021.066

\section{ЗНАЧИМОСТЬ АНАЛИЗА ЛИПИДНЫХ ЭКСТРАКТОВ ИЗ ОТДЕЛЯЕМОГО ЦЕРВИКАЛЬНОГО КАНАЛА ДЛЯ ДИАГНОСТИКИ ПЛАЦЕНТА-АССОЦИИРОВАННЫХ ОСЛОЖНЕНИЙ БЕРЕМЕННОСТИ}

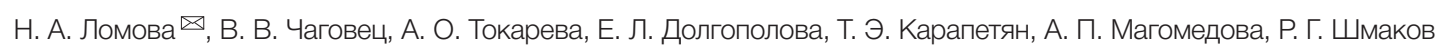

Национальный медицинский исследовательский центр акушерства, гинекологии и перинатологии имени В. И. Кулакова, Москва, Россия

Использование омиксных технологий имеет на сегодняшний день большой потенциал для разработки новых диагностических подходов в акушерстве. Цервико-вагинальная жидкость (ЦВЖ) как часть системы «мать-плацента-плод» может быть использована для диагностики акушерских осложнений. Целью исследования было выявить особенности липидного состава отделяемого цервикального канала у беременных с задержкой роста плода и преэклампсией. Выполнен углубленный клинико-анамнестический и масс-спектрометрический анализ ЦВЖ, полученный от 57 беременных женщин. Липидные экстракты ЦВЖ анализировали на жидкостном хроматографе, соединенном с масс-анализатором. В результате исследования идентифицировано 239 соединений липидов. Математический анализ выявил значимые различия между пациентками группы нормы и с задержкой развития плода (ЗРП) для 17 липидов ( $>$ < 0,05). Между пациентками группы нормы и преэклампсии (ПЭ) значимые различия были обнаружены для трех липидов (p < 0,05). Между пациентками с ПЭ и пациентками с ЗРП статистически значимая разница в уровнях была выявлена для двух липидов (p < 0,05). Показано, что липиды относились преимущественно к классам оксилипидов, сфингомиелинов, триглицеридов и кардиолипинов. При построении диагностической модели достигнута чувствительность 0,81 и специфичность 0,91 (порог отсечки - 0,50; AUC - 0,85). Полученные данные перспективны для разработки методов диагностики плацента-ассоциированных осложнений беременности и понимания новых механизмов патогенеза данных осложнений.

Ключевые слова: прогностическая значимость, неинвазивная диагностика, преэклампсия, задержка роста плода, липидомика

Финансирование: исследование выполнено при поддержке государственного задания Министерства здравоохранения Российской Федерации [Государственный регистрационный номер. АААА-А18-118053190026-6].

Благодарности: авторы выражают особую благодарность д.ф.-м.н., руководителю отдела системной биологии в репродукции Национального медицинского исследовательского центра акушерства, гинекологии и перинатологии имени В. И. Кулакова В. Е. Франкевичу за помощь В подготовке исследования, систематическом анализе и редактировании рукописи.

Вклад авторов: Н. А. Ломова - анализ клинических данных, систематический анализ, написание рукописи; В. В. Чаговец - проведение метаболомного анализа методом масс-спектрометрии, статистический анализ полученныхданных, редактирование рукописи; А. О. Токарева - проведение метаболомного анализа методом масс-спектрометрии, обработка масс-спектрометрических данных; Е. Л. Долгополова - сбор и подготовка биологических сред, статистический анализ результатов; Т. Э. Карапетян - анализ клинических данных, статистический анализ результатов; А. П. Магомедова - сбор и подготовка биологических сред; Р. Г. Шмаков - анализ клинических данных, систематический анализ, редактирование рукописи.

Соблюдение этических стандартов: исследование одобрено этическим комитетом НЦАГиП им. В. И. Кулакова (протокол № 11 от 11 ноября 2021 г.), проведено в соответствии с требованиями Хельсинкской декларации, Международной конференции по гармонизации (ICF), Стандартами надлежащей клинической практики (GCP), ФЗ «Об основах охраны здоровья граждан в Российской Федерации»; все пациентки подписали добровольное информированное согласие на участие в исследовании.

$\searrow$ Для корреспонденции: Наталья Анатольевна Ломова

ул. Академика Опарина, д. 4, г. Москва, 117997; natasha-lomova@yandex.ru

Статья получена: 23.11.2021 Статья принята к печати: 20.12.2021 Опубликована онлайн: 29.12.2021

DOI: $10.24075 /$ vrgmu.2021.066 
It has earlier been established that such common complications of pregnancy as Intrauterine Growth Restriction (IUGR) and preeclampsia (PE) are associated with placental dysfunction. With these pathologies, metabolic and circulatory systems fail to adapt to changes caused by pregnancy, which leads to hypertension and impaired placental blood flow. This not only causes undesirable consequences for the health of the mother and child during gestation, but can also affect their future health. In recent years, 10 to $20 \%$ of pregnancies in the economically developed countries have been complicated by some form of hypertension [1]. Preeclampsia is a pregnancy complication that occurs in the placenta and negatively affects both the mother and the fetus. PE is diagnosed in $5-7 \%$ of pregnant women worldwide [2]. This condition can develop after 20th week of pregnancy; its manifestations are hypertension, proteinuria and edema. Subsequently, it causes fetal distress and diminishes the chances of positive pregnancy outcome. IUGR prevents the fetus from realizing its growth potential in full: the weight and the body mass index (BMI) of the newborn are abnormal for the respective number of gestational weeks. About $4-8 \%$ of newborns are diagnosed with IUGR in industrialized countries, and in the developing countries this figure ranges from 6 to $30 \%[3,4]$. The causes of IUGR are distinguished into internal, peculiar to the fetus or placenta, and external, the mother-side factors affecting mainly the placenta and the fetus. There are also combinations of internal and external IUGR causes.

To date, there have not been developed adequate methods of prediction of these pregnancy complications, which obviously necessitates development of non-invasive and objective methods of prenatal diagnostics and monitoring.

Today, post-genomic omics technologies, including metabolomics and lipidomics, are growing rapidly and become more and more common in the routine clinical practice. With regard to the pathologies considered in this work, significant changes in the levels of metabolites were found even before preeclampsia manifested clinically, and these changes increase with the progression of the disorder [5-7]. Metabolomics can help detect the specific features of these conditions at the molecular level and aid in identification of the biological mechanisms underlying them, as well as in discovery of the new biomarkers. Metabolomics also offers a unique set of tools enabling identification of various endotypes of pathological conditions [7, 8] and diagnosing of different complications of pregnancy. Similar observations have been made for IUGR [9]. In the aforementioned works, researchers analyzed blood metabolome. Blood sampling is an invasive method of obtaining biological material. This study discusses the possibility of using cervical canal secretion to make PE or IUGR development prediction non-invasive.

Currently, the search for non-invasive and minimally invasive diagnostic markers in obstetrics is a promising area of scientific research. Cervical canal is one of the potential loci for minimally invasive sampling of biological material. There have been described potential biomarkers of spontaneous preterm labor that were identified through targeted proteomic analysis of cervicovaginal fluid samples from asymptomatic high-risk women. The proteins in cervicovaginal fluid of patients that experienced spontaneous preterm labor are extracellular matrix proteins that can also regulate the physiology of cell membranes [10]. In 2020, a statistically significant difference in the level of cytokines from cervicovaginal fluid samples, especially IL6 and $\mathrm{IL} 17 \alpha$, was found in the group of women with preterm labor and premature rupture of the membranes in the history. These indicators may be more accurate prognostic markers of preterm labor than fetal fibronectin that is the standard indicator relied on in clinical practice today [11]. During pregnancy, dysbiosis of the vaginal microbiota directly affects metabolic profiles, which can trigger premature birth. In 2020, researchers used nuclear magnetic resonance spectroscopy to analyze metabolic profile of cervicovaginal fluid and identified metabolic markers that can help predict preterm labor. The assessment of the ROC curve showed that acetone, ethylene glycol, formate, glycolate, isopropanol, methanol, and trimethylamine oxide were the best in the matter of predicting preterm labor. These metabolites can be useful markers clinically and for prognosis of preterm labor [12]. Thus, to date, it has been proven that the cervicovaginal fluid, which is part of the mother-placenta-fetus system, contains a number of biologically active components that can potentially be used for predicting and diagnosing obstetric pathology.

There is a wide range of methods applied to identify and validate biomarkers in metabolomic studies: ultraviolet and infrared spectroscopy, nuclear magnetic resonance spectroscopy, electrophoresis. However, the most common are metabolomic platforms based on liquid chromatography with mass spectrometric detection (LC-MS).

Metabolomics as part of studies of obstetric syndromes associated with placental insufficiency (PE and IUGR) can greatly facilitate understanding of the pathogenesis of these complications of pregnancy and development of new diagnostic and prognostic approaches.

The purpose of the study was to search for differences in the lipids of cervical canal secretion of patients with normal pregnancy and patients with fetal growth retardation and preeclampsia, as well as to develop mathematical models based on the differences found with the aim to create noninvasive methods for antenatal diagnosis of PE and IUGR .

\section{METHODS}

This was a case-control study conducted at the Kulakov National Medical Research Center for Obstetrics, Gynecology and Perinatology (Russia) from January to December 2020. The study involved 57 pregnant women, observed and helped to deliver within the study timeframe in the Center. The women were divided into three groups: Group I - 18 patients with preeclampsia, Group II - 19 patients with IUGR , Group III - 20 pregnant women without these complications, conditionally healthy (control group). Group I inclusion criteria: $\mathrm{SBP} \geq 140 \mathrm{mmHg}$ and/or DBP $\geq 90 \mathrm{mmHg}$ after 20th week of pregnancy regardless of the history of blood pressure, in combination with proteinuria $\geq 0.3 \mathrm{~g}$ per day or $\geq 0.3 \mathrm{~g} / \mathrm{l}$ in two portions of urine taken 6 hours apart. Group II inclusion criteria: IUGR diagnosed through a ultrasound study, if there was a slowdown in the rate of increase of the estimated fetal weight (EFW) and/or abdominal circumference $(A C)<10^{\text {th }}$ percentile, in combination with pathological blood flow as shown with Doppler ultrasonography or EFW and/or AC values $<3^{\text {rd }}$ percentile. Exclusion criteria: multiple pregnancy, cervical pathology, diabetes mellitus, impaired renal function, chronic arterial hypertension, oncological and infectious-inflammatory diseases during this pregnancy. This study did not include the cases of combined PE and IUGR. All patients delivered by caesarean section.

\section{Collection and preparation of samples}

On the day of admission to the Center, all pregnant women included in the study had their cervicovaginal secretion sampled before vaginal examination. To detect any infectious 
Table 1. Clinical characteristics of the groups

\begin{tabular}{|l|c|c|c|c|c|c|}
\hline \multirow{2}{*}{ Parameter } & \multicolumn{3}{|c|}{ Descriptive parameter statistics } & \multicolumn{2}{c|}{$\begin{array}{c}\text { Statistical significance of differences in parameters in } \\
\text { pairwise comparison of groups }(p \text {-value) }\end{array}$} \\
\cline { 2 - 7 } & PE $(n=18)$ & $\begin{array}{c}\text { IUGR } \\
(n=19)\end{array}$ & $\begin{array}{c}\text { Normal } \\
(n=20)\end{array}$ & PE-Normal & IUGR-Normal & PE-UGR \\
\hline Age, years & $31 \pm 5$ & $34 \pm 8$ & $31 \pm 5$ & 0,769 & 0,21 & 0,331 \\
\hline BMI & $28 \pm 4$ & $23 \pm 4$ & $27 \pm 3$ & 0,666 & 0,005 & 0,0045 \\
\hline Delivery time, weeks & $36 \pm 3$ & $37 \pm 3,1$ & $40 \pm 1$ & $<0,001$ & $<0,001$ & 0,342 \\
\hline Birth height, cm & $46,6 \pm 4,5$ & $45,2 \pm 5,3$ & $52,6 \pm 2,4$ & 0,001 & $<0,001$ & 0,452 \\
\hline Birth weight, g & $2341 \pm 633,6$ & $2128,7 \pm 602$ & $3493,6 \pm 303,6$ & $<0,001$ & $<0,001$ & 0,383 \\
\hline Apgar score, first minute & $8(7 ; 8)$ & $8(8 ; 8)$ & $8(8 ; 8)$ & 0,04 & 0,135 & 0,845 \\
\hline Apgar score, fifth minute & $9(8 ; 9)$ & $9(8 ; 9)$ & $9(9 ; 9)$ & 0,131 & 0,05 & 0,859 \\
\hline
\end{tabular}

and inflammatory diseases of the urogenital tract, a smear was taken to established cleanliness and microbiological composition of the vagina. On average, the samples were taken 10-14 days before delivery.

The cervicovaginal secretion samples were collected with a disposable vaginal elevator and sterile disposable cytobrushes. After introduction of the elevator and visual identification of the external canal of the cervix, a cytobrush was inserted into the cervical canal to a depth of $0.5 \mathrm{~cm}$ and, after a clockwise rotation, removed in such a way as to avoid contact with the walls of the vagina and external genital organs. After collection the samples were cooled in liquid nitrogen and stored at $-80^{\circ} \mathrm{C}$.

Before analysis, the samples were subjected to liquid-liquid extraction to obtain the lipid fraction. For this purpose, $500 \mu \mathrm{L}$ of an $\mathrm{H}_{2} \mathrm{O}$ /methanol (1:1) solution were added to the test tube with the cytobrush, then mixed thoroughly for 5 minutes and sonicated for another 5 minutes. After that, the cytobrush was removed from the test tube, $1 \mathrm{ml}$ of chloroform added thereto and the tube stirred for 10 minutes. Next, it was centrifuged for 5 minutes at $13000 \mathrm{G}$ at ambient temperature, $925 \mu \mathrm{L}$ of the lower layer taken, dried in a nitrogen flow and redissolved in $200 \mu \mathrm{L}$ of isopropanol/acetonitrile (1:1) solution for further analysis.

\section{Mass spectrometric analysis of lipid extracts}

Lipid extracts were analyzed in a Dionex UltiMate 3000 liquid chromatography system (Thermo Scientific; Germany) connected to a MaXis Impact qTOF mass analyzer with an electrospray ionization source (Bruker Daltonics; Germany). Samples were separated by reversed-phase chromatography in a Zorbax C18 column $(150 \times 2.1 \mathrm{~mm}, 5 \mu \mathrm{m}$; Agilent, United States) with a linear gradient from 30 to $90 \%$ of eluent B in 20 minutes. Eluent $A$ was a 60:40 acetonitrile/water solution with

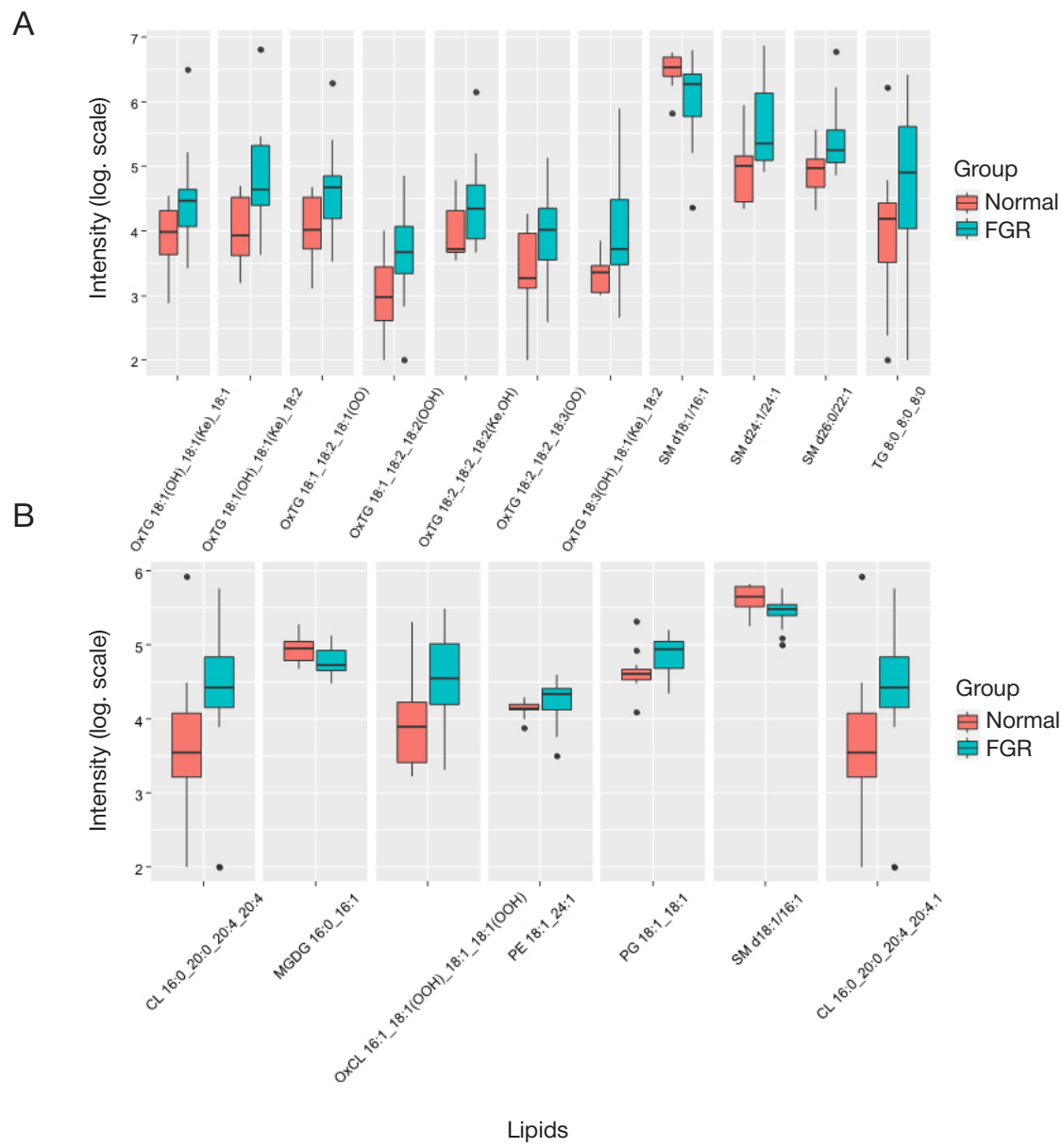

Fig. 1. Plotting of lipid levels. Significant differences between lipid levels, comparison of the normal and the IUGR groups, positive ion mode (A) and negative ion mode (B) 

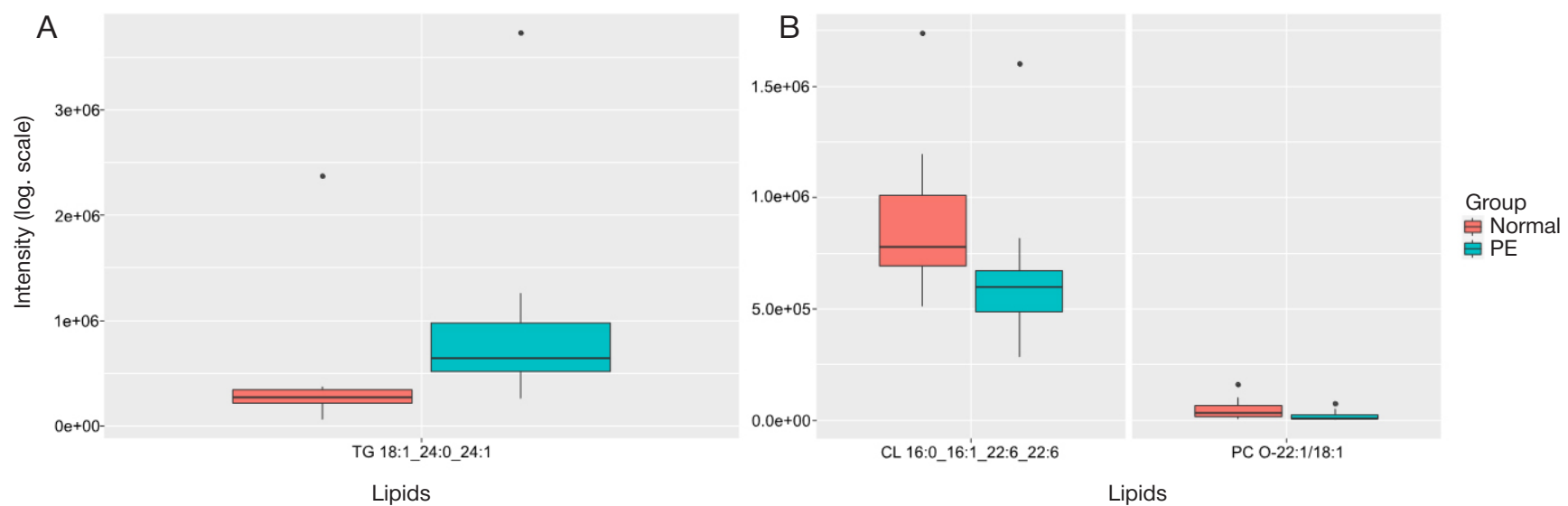

Fig. 2. Plotting of lipid levels. Significant differences between lipid levels, comparison of the normal and the PE groups, positive ion mode (A) and negative ion mode (B)

some $0.1 \%$ formic acid and $10 \mathrm{mmol} / \mathrm{L}$ ammonium formate; eluent B was a 90:8:2 isopropanol/acetonitrile/water solution with some $0.1 \%$ formic acid and $10 \mathrm{mmol} / \mathrm{L}$ ammonium formate. The elution flow rate was $40 \mu \mathrm{L} / \mathrm{min}$, and the volume of the injected sample was $3 \mu \mathrm{L}$. The mass spectra were obtained in the positive and negative ions mode in the range of $\mathrm{m} / \mathrm{z}$ 100-1700 Da, with the following settings: voltage across the capillary at $4.1 \mathrm{kV}$ in the positive ion mode and $-3.2 \mathrm{kV}$ in the negative ion mode; pressure of the sputtering gas at 0.7 bar, drying gas flow rate $6 \mathrm{~L} / \mathrm{min}$, drying gas temperature $200^{\circ} \mathrm{C}$.

The initial mass spectrometric data were processed with the help of msConvert software from the Proteowizard 3.0.9987 package [13], MzMine [14]. Lipid identification was performed with LipidMatch scripts [15] using the exact mass and characteristic tandem mass spectra (MS/MS). The list of lipids is consistent with LipidMaps [16]

\section{Statistical analysis}

We used scripts written in the R language version 3.3.3 [17] and RStudio 1.383 [18] to process the results statistically.

The analyzed parameters were checked against the law of normal distribution with the help of Shapiro-Wilk test. When the distribution of the examined value was normal, we used the Student's t test for statistical analysis, and for the abnormal distribution cases we relied on the Mann-Whitney test for pairwise comparisons. To describe the quantitative data with normal distribution, we used arithmetic mean (M) and standard deviation $(S D)$ in the $M(S D)$ format. Features with distribution different from normal were described as a median $(\mathrm{Me})$ and quartiles $Q_{1}$ and $Q_{3}$ in the Me format $\left(Q_{1} ; Q_{3}\right)$. The value of the threshold significance level $p$ was taken at 0.05 .

We developed the logistic regression models in order to assess the possibility of classifying patients into groups. Lipids showing statistically significant differences in levels between the groups were independent variables in the models. Akaike information criterion (AIC) enabled selection of the variables [19]. We continued selecting variables in stages while this action resulted in an increase in AIC. The quality of the resulting diagnostic model was tested by internal crossvalidation with control for individual objects. The values of the area under the operating curve, sensitivity and specificity were used for assessment. The patient's group membership was the dependent variable. For each model, we determined the Wald test, 95\% confidence interval $(\mathrm{Cl})$, odds ratio (OR) and its confidence interval. The quality of the developed models was determined by constructing the ROC curve, determining the area under the ROC curve, and calculating the sensitivity and specificity.

\section{RESULTS}

Table 1 gives the results of analysis of the clinical parameters of the groups.

It was found that the BMl of pregnant women from the IUGR group is significantly lower than that of women in the "normal" and "preeclampsia" groups $(p=0.005$ and $p=0.0045$, respectively).

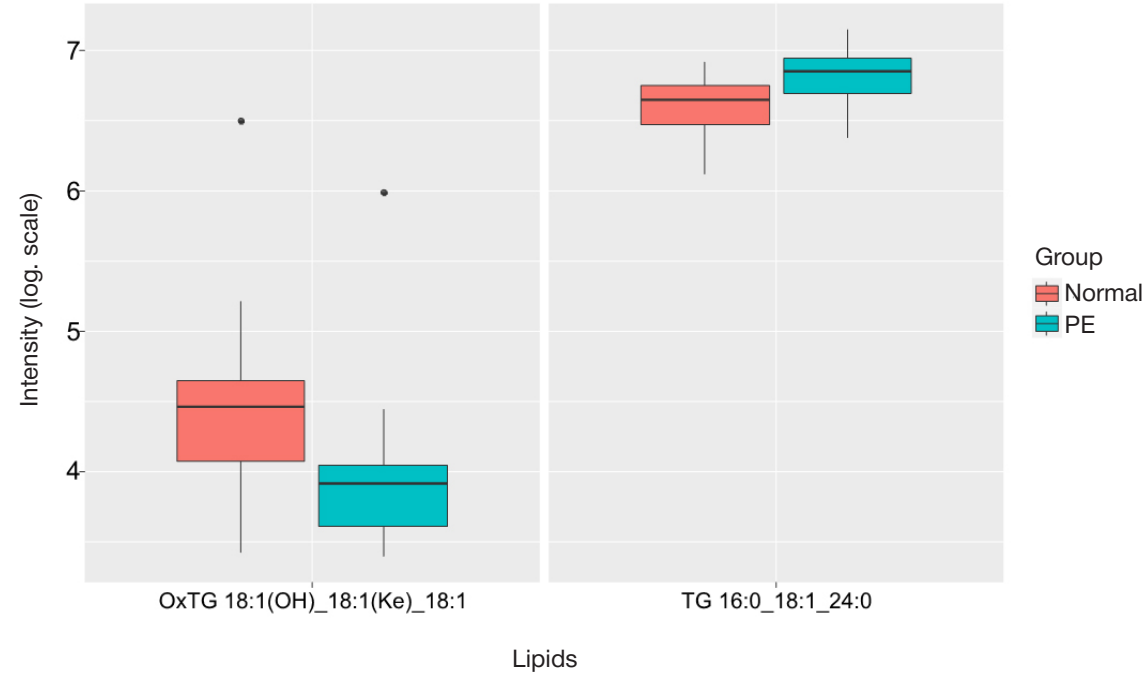

Fig. 3. Plotting of lipid levels. Significant differences between lipid levels, comparison of the PE and the IUGR groups, positive ion mode 
Table 2. Characteristics of the components used to build logistic regression models enabling allocation of the patients to the IUGR, PE and Normal (control) groups by the lipid profile established for the cervical canal secretion: independent variable, its coefficient $\beta$, confidence interval (Cl) of $\beta$, Wald test, probability of coefficient value differing from $\mathrm{P}$ zero

\begin{tabular}{|c|c|c|c|c|}
\hline Lipids & $\beta$ & ди $\beta$ & Wald test & $p$ \\
\hline \multicolumn{5}{|c|}{ IUGR/Normal, positive ion mode } \\
\hline Free term & $-0,93$ & $-2,63-0,43$ & $-1,20$ & 0,23 \\
\hline $\begin{array}{c}\text { OxTG } \\
18: 3(\mathrm{OH}) \_18: 1(\mathrm{Ke}) \_18: 2\end{array}$ & $3,01 \cdot 10^{-4}$ & $5,99 \cdot 10^{-5}-8,16 \cdot 10^{-4}$ & 1,38 & 0,17 \\
\hline \multicolumn{5}{|c|}{ IUGR/Normal, negative ion mode } \\
\hline Free term & $-10,73$ & $-31,29-1,54$ & $-1,62$ & 0,1 \\
\hline SM d22:3/22:4 & $3,20 \cdot 10^{-3}$ & $6,28 \cdot 10^{-4}-8,88 \cdot 10^{-3}$ & 1,65 & 0,1 \\
\hline PE 18:1_24:1 & $5,84 \mathrm{e}-04$ & $1,72 \cdot 10^{-4}-1,49 \cdot 10^{-3}$ & 1,96 & 0,05 \\
\hline MGDG 16:0_16:1 & $-3,01 \cdot 10^{-5}$ & $-8,54 \cdot 10^{-5}-4,33 \cdot 10^{-6}$ & $-1,45$ & 0,15 \\
\hline \multicolumn{5}{|c|}{ PE/Normal, positive ion mode } \\
\hline Free term & $-0,75$ & $-2,23-0,45$ & $-1,14$ & 0,25 \\
\hline TG 18:1_24:0_24:1 & $1,06 \cdot 10^{-6}$ & $-2,27 \cdot 10^{-7}-3,53 \cdot 10^{-6}$ & 1,19 & 0,24 \\
\hline \multicolumn{5}{|c|}{ PE/IUGR, positive ion mode } \\
\hline Free term & 2,71 & $0,71-5,45$ & 2,31 & 0,02 \\
\hline TG 16:0_18:1_24:0 & $-3,91 \cdot 10^{-7}$ & $-8,39 \cdot 10^{-7}-7,62 \cdot 10^{-8}$ & $-2,07$ & 0,04 \\
\hline
\end{tabular}

All women delivered in the third trimester of pregnancy. The delivery time for the PE and IUGR groups significantly differed from that for the control group $(p<0.001)$, which is explained by the need for accelerated delivery based on obstetric indications. The share of preterm delivery in the PE group was $33.3 \%$ (six cases), in the IUGR group - $31.6 \%$ (six cases).

The average weight of newborns in the control group was $3493.6 \mathrm{~g}$, compared to $2341 \mathrm{~g}$ and $2128.7 \mathrm{~g}$ in PE and IUGR groups, respectively $(p \leq 0.001)$.

It should be noted that, compared to the control group, the Apgar score in the PE group was significantly lower at the first minute of life $(p=0.04)$ and in the IUGR group - at the fifth minute $(p=0.05)$. One of the possible reasons behind the observations is that a newborn that suffered chronic hypoxia and growth retardation for a long period has the reserves of his/ her compensatory mechanisms depleted and experiences early neonatal adaptation in severe form. One child was diagnosed with moderate asphyxia at birth, which required additional respiratory support.

Analysis of lipid composition of the cervical canal secretion was enabled by LC-MS. LC-MS experiments were performed in both positive and negative ion modes, since this approach allows expanding the coverage of registered and identified lipids. LC-MS in positive ion mode allowed identifying 129 lipids, LC-MS in negative ion mode-110 lipid compounds. Comparison of the relative lipid levels between the control group and the IUGR group revealed 10 lipids with levels differing significantly as registered in positive ion mode and 7 lipids with significantly different levels as registered in negative ion mode (Fig. 1). The results of the comparison of control and PE groups were 1 lipid with significant level difference found in positive ion mode analysis and 2 such lipids discovered negative ion mode (Fig. 2). As for the PE to IUGR groups comparison, there were two lipids the levels of which differed significantly (Fig. 3). Mainly, the lipids were oxylipins (oxytriglycerides and oxycardiolipins), sphingomyelins, triglycerides, and cardiolipins.

Relying on the data obtained, we built the logistic regression models seeking to identify patients who may develop IUGR or PE, such identification based on the levels of lipids in the cervical canal secretion (Table 2). A ROC analysis enabled assessment of quality of the built models; Table 3 and Figures 4 and 5 present the results of this analysis. The models enabling allocation to the control and the IUGR groups had the best parameters; they made use of data obtained with both positive ion mode and negative ion mode. The AUC was 0.70 and 0.85 , respectively. The model that enabled allocation to the PE and control groups had a rather high specificity (0.91) but low sensitivity (0.30). Thus, of the obstetric pathologies considered in this work (IUGR and PE), the non-invasive approach to lipid profiling based on the cervical canal secretion seems most promising for detection of IUGR. As for PE diagnosing, applicability of the described approach requires additional research. The IUGR /Normal and IUGR /PE models built on the positive ion mode and negative ion mode data can be considered for further improvement and validation.

\section{DISCUSSION}

The study allowed identifying 129 lipids with positive ion mode and 110 lipid compounds with negative ion mode; they are simple lipids, glycerides and complex lipids, which in turn are divided into glycerophospholipids and sphingolipids. The natural organic compounds of this large group, including fats and fat-like substances, participate in construction of cell membranes and regulation of metabolism. The group is undoubtedly interesting as a research subject in the context

Table 3. Characteristics of the logistic regression models enabling allocation of the patients to the IUGR, PE and Normal (control) groups by the lipid profile established for the cervical canal secretion. PPV — positive predictive value, NPV — negative predictive value

\begin{tabular}{|c|c|c|c|c|c|c|c|}
\hline Patient groups & $\begin{array}{l}\text { MS technique (positive ion/ } \\
\text { negative ion) }\end{array}$ & Sensitivity & Specificity & Threshold & AUC & PPV & NPV \\
\hline IUGR/Normal & positive & 0,63 & 0,91 & 0,2 & 0,7 & 0,6 & 0,89 \\
\hline IUGR/Normal & positive & 0,81 & 0,91 & 0,5 & 0,85 & 0,79 & 0,9 \\
\hline PE/Normal & positive & 0,3 & 0,91 & 0,1 & 0,67 & 0,27 & 0,88 \\
\hline IUGR/PE & positive & 0,67 & 0,6 & 0,5 & 0,66 & 0,6 & 0,58 \\
\hline
\end{tabular}


A

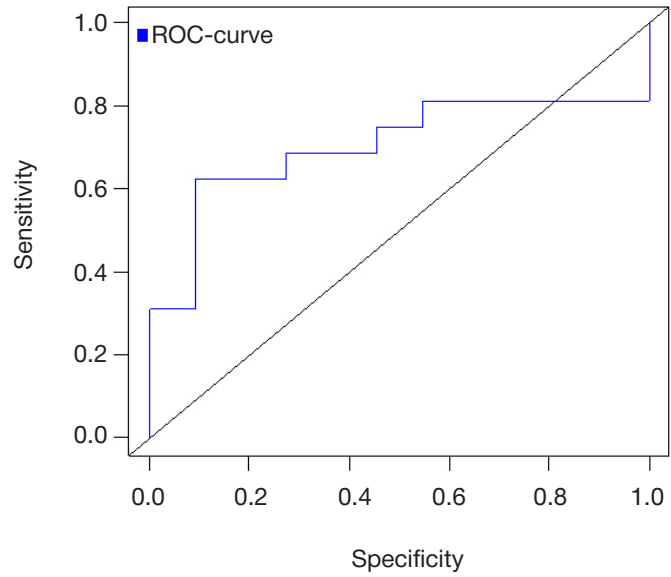

B

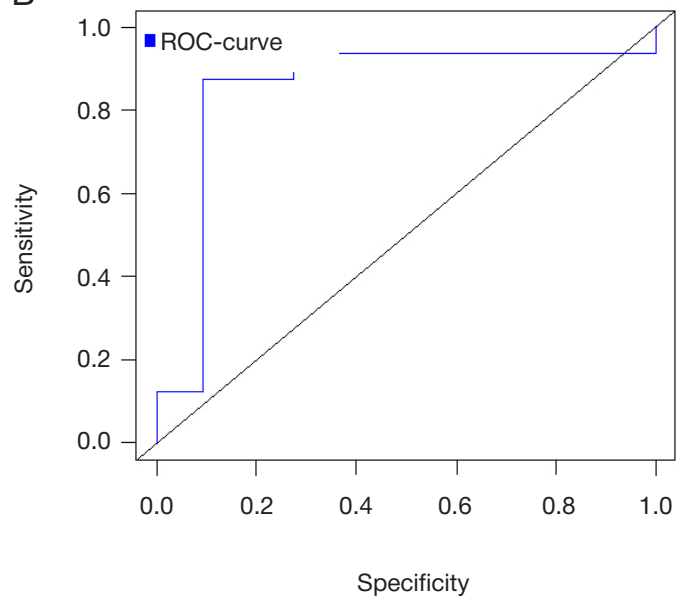

Fig. 4. Operational curve plotted for the IUGR/Normal model based on the positive ion mode (A) and negative ion mode (B) data

of obstetric pathologies. In particular, there may be value in investigation of changes in the group associated with the said pathologies and, specifically, tracking the fluctuations at the interface of the mother-placenta-fetus system. Fatty acids and lipids play a primary role in growth and development during the embryonic period. Unbalanced intake of fatty acids during the perinatal period alters the composition of fatty acids in the membrane phospholipids of the fetus, which can cause structural and functional problems in its cells. In addition, the metabolic and neuroendocrine environment of the fetus and the newborn plays a key role in the energy balance regulation. Lack of proper balance between fatty acids and lipids during pregnancy can lead to irreversible changes in the control of neuroendocrine function and energy metabolism in the fetus, leading to metabolic programming. Thus, control of the lipid levels enables detection of abnormalities in the motherplacenta-fetus system even at the preclinical stage [20]. It has been shown (in both animal and human experiments) that the metabolic pathway of sphingolipids plays a critical role in fetal and maternal tolerance, regulating innate immunity at the mother-fetus interface. These findings may help develop new therapeutic strategies for obstetric complications [21].

During pregnancy, metabolic changes occur in all systems and processes of the woman's body, including lipid metabolism. Cholesterol and free fatty acids are essential for cellular synthesis of embryonic membranes. The fetus synthesizes lipids and makes extensive use of maternal lipids, although free transplacental transport of maternal lipoproteins is limited by the "placental barrier" [22]. Phospholipids and

A

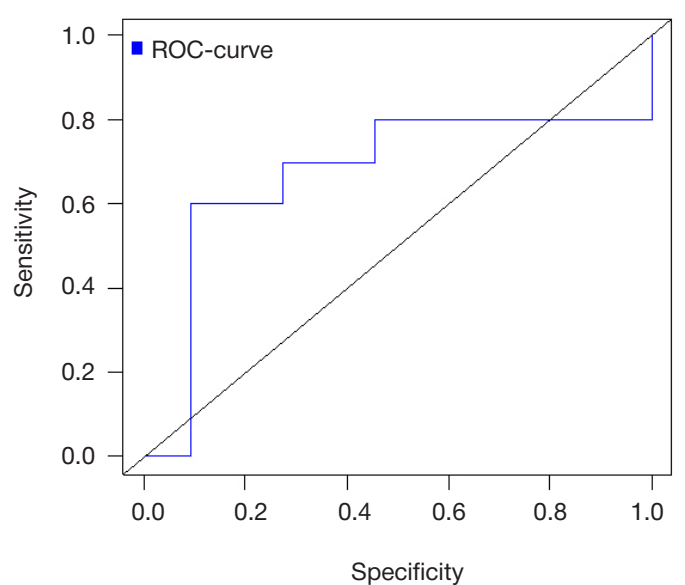

triacylglycerols (TAGs) from the mother's body do not penetrate directly to the fetus. There is a number of mechanisms enabling transportation of fatty acids to the fetus; these mechanisms imply binding fatty acids [23] and transporting them intensively across the placenta. Circulating lipids have a variety of effects on the endothelial cell function. Dyslipidemia is often associated with dysfunction of these cells [24]. Several studies have shown a concentration-dependent relationship between elevated TAG levels and the risk of PE. There are many mechanisms that may be used as explanation of the correlation between dyslipidemia and PE. For example, increased levels of lipid fractions (such as TAG) trigger their accumulation in endothelial cells and subdue production of prostacyclin, which subsequently leads to endothelial dysfunction [25]. In our study, the level of TG 18: 1_24:0_24: 1, CL 16: 0_16:1_22: 6_22: 6, PC O-22: 1/18: 1 had significant differences in the PE-Normal groups comparison ( $p=0.008, p=0.02, p=0.04$, respectively). The specificity achieved for the PE/Normal diagnostic model is 0.91 (cut-off threshold - 0.10; AUC - 0.67).

In case of IUGR, placenta does not function properly and has its structure compromised, and the manifestations of the problem are detectable with the fetus but not with the mother's body. Several researchers $[26,27]$ have found that during pregnancy complicated by IUGR, there is a decrease in the level of lipids in the umbilical cord blood and the mother's blood, and the number of their receptors goes down, too. Low levels of lipids and their receptors in the feto-placental complex will probably have very serious consequences for the normal growth and development of the fetus, since they

B

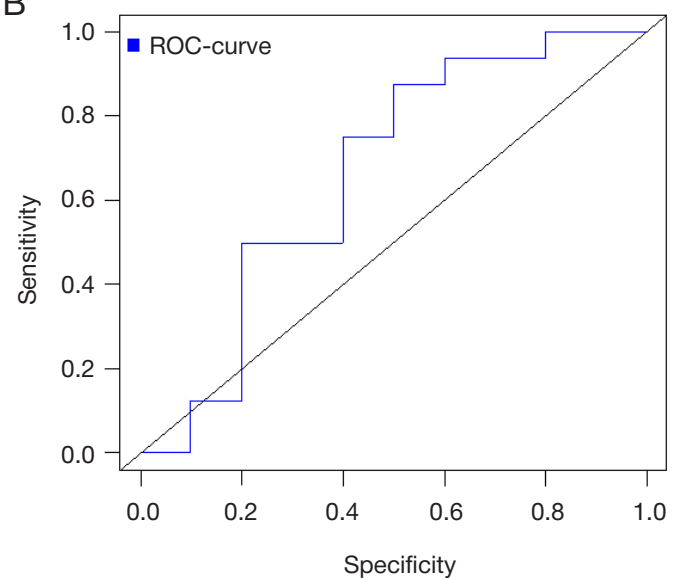

Fig. 5. Operational curve plotted for the PE/Normal model (A), IUGR/PE model based on the positive ion mode data (B) 
will only insufficiently enable transport of cholesterol, normal functioning of the placenta and harmonious growth of the fetus. As we have registered in our study, the levels of 17 lipids (Table 2) were significantly different in the IUGR and the Normal groups $(p<0.05)$. The specificity achieved for the PE/Normal diagnostic model is 0.91 , sensitivity is 0.81 (cut-off threshold -0.50; AUC - 0.85).

The significant difference in the results of examination of cervicovaginal secretion samples taken in the IUGR and PE groups $(p=0.04)$ is of particular interest. This difference clearly demonstrates that these pregnancy complications, initially considered to stem from the common placental dysfunction, are not the same on the pathogenetic level.

\section{CONCLUSIONS}

Our study clearly demonstrates the possibility of using cervicovaginal fluid in complex diagnostic monitoring of pregnant women with placenta-associated obstetric complications. We performed an in-depth clinical-anamnestic and massspectrometric analysis of samples taken from 57 pregnant women. Analysis of the cervical canal secretion of pregnant women with IUGR and PE revealed 129 lipid compounds when using LC-MS in positive ion mode and 110 lipid compounds with LC-MS in negative ion mode. The level of a number of lipids differed significantly between the PE and Normal groups and the IUGR and Normal groups. This observation may indicate the existing differences in the chain of biological processes of the pathogenesis of these pregnancy complications that are commonly believed to stem from placental dysfunction. Further research in this direction may help identify new approaches to the development of targeted therapy for the "major obstetric syndromes." The lipids were mainly oxylipins (oxytriglycerides and oxycardiolipins), sphingomyelins, triglycerides, and cardiolipins, which means this method may be used as part of a complex of predictive measures. Based on the differences identified, we built logistic regression models that can contribute to the development of methods of non-invasive diagnostics of these diseases. The result of our effort is the clear demonstration of the possibility to determine the level of lipids in the cervicovaginal fluid noninvasively in the context of complex diagnostic monitoring of pregnant women with placenta-associated obstetric complications.

\section{References}

1. Sutton ALM, Harper LM, Tita ATN. Hypertensive Disorders in Pregnancy. Obstet Gynecol Clin North Am. 2018; 45 (2): 333-47.

2. Gestational Hypertension and Preeclampsia. Obstet Gynecol. 2020; 135 (6): 1492-5

3. Nardozza LMM, Caetano ACR, Zamarian ACP, Mazzola JB Silva CP, Marçal VMG, et al. Fetal growth restriction: current knowledge. Arch Gynecol Obstet. 2017; 295 (5): 1061-77.

4. Gaccioli F, Lager S. Placental Nutrient Transport and Intrauterine Growth Restriction. Front Physiol. 2016; 7. DOI: 10.3389/ fphys.2016.00040

5. Benton SJ, Ly C, Vukovic S, Bainbridge SA. Andrée Gruslin award lecture: Metabolomics as an important modality to better understand preeclampsia. Placenta. 2017; 60: S32-S40.

6. Kenny LC, Broadhurst D, Brown M, Dunn WB, Redman CWG, Kell DB, et al. Detection and identification of novel metabolomic biomarkers in preeclampsia. Reprod Sci. 2008; 15 (6): 591-7.

7. Anderson, Deborah K., Liang JW and CL. Applications of Metabolomics in the Study and Management of Preeclampsia; A Review of the Literature Rachel. Metabolomics. 2017; 13 (7): 86.

8. Comhair SAA, McDunn J, Bennett C, Fettig J, Erzurum SC Kalhan SC. Metabolomic Endotype of Asthma. J Immunol. 2015 195 (2): 643-50.

9. Moros G, Boutsikou T, Fotakis C, lliodromiti Z, Sokou R, Katsila T, et al. Insights into intrauterine growth restriction based on maternal and umbilical cord blood metabolomics. Sci Rep. 2021; 11 (1): 1-10.

10. Parry S, Leite R, Esplin MS, Bukowski R, Zhang $H$, Varner $M$, Andrews WW, Saade GR, llekis J, Reddy UM, Huang $H$, Sadovsky Y, Blair IA, Biggio J; Cervicovaginal fluid proteomic analysis to identify potential biomarkers for preterm birth. Am $J$ Obstet Gynecol. 2020; 222 (5): 493.e1-493.e13. DOI: 10.1016/j. ajog.2019.11.1252. Epub 2019 Nov 20.

11. Park S, You YA, Yun H, Choi SJ, Hwang HS, Choi SK, Lee SM, Kim YJ. Cervicovaginal fluid cytokines as predictive markers of preterm birth in symptomatic women. Obstet Gynecol Sci. 2020 63 (4): 455-63. DOI: 10.5468/ogs.19131. Epub 2020 Jun 19.

12. AbuZar Ansari, Heeyeon Lee, Young-Ah You, Youngae Jung, Sunwha Park, Soo Min Kim, Geum-Sook Hwang, Young Ju Kim. Identification of Potential Biomarkers in the Cervicovaginal Fluid by Metabolic Profiling for Preterm Birth Metabolites. 2020; 10 (9): 349. DOI: 10.3390/metabo10090349.

13. Chambers MC, MacLean B, Burke R, Amodei D, Ruderman DL, Neumann S, et al. A cross-platform toolkit for mass spectrometry and proteomics. Nature Biotechnology. 2012; 30 (10): 918-20.

14. Pluskal T, Castillo S, Villar-Briones A, Orešič M. MZmine 2: Modular framework for processing, visualizing, and analyzing mass spectrometry-based molecular profile data. BMC Bioinformatics. 2010; 11. DOI: 10.1186/1471-2105-11-395.

15. Koelmel JP, Kroeger NM, Ulmer CZ, Bowden JA, Patterson RE, Cochran JA, et al. LipidMatch: An automated workflow for rulebased lipid identification using untargeted high-resolution tandem mass spectrometry data. BMC Bioinformatics. 2017; 18 (1): 1-11.

16. Liebisch G, Vizcaíno JA, Köfeler H, Trötzmüller M, Griffiths WJ, Schmitz G, et al. Shorthand notation for lipid structures derived from mass spectrometry. J Lipid Res. 2013; 54 (6): 1523-30.

17. R : A Language and Environment for Statistical Computing. 2018. Vienna, Austria. R Foundation for Statistical Computing.

18. R team. R Studio: Integrated Development for R. 2016.

19. Bozdogan H. Model selection and Akaike's Information Criterion (AIC): The general theory and its analytical extensions. Psychometrika. 1987; 52 (3): 345-70.

20. Kabaran S, Besler HT. Do fatty acids affect fetal programming? J Health Popul Nutr. 2015; 33: 14. DOI: 10.1186/s41043-0150018-9.PMID: 26825664.

21. Mizugishi $K$, Inoue T, Hatayama H, Bielawski J, Pierce JS, Sato $Y$, Takaori-Kondo A, Konishi I, Yamashita K. Sphingolipid pathway regulates innate immune responses at the fetomaternal interface during pregnancy. J Biol Chem. 2015; 290 (4): 2053-68. DOI: 10.1074/jbc.M114.628867. Epub 2014 Dec 11.PMID: 25505239.

22. Herrera E. Maternal-fetal transfer of lipid metabolites. In: RA Polin, WW Fox, SH Abman, editors. Fetal and Neonatal Physiology. 2004; p. 375-388.

23. Pogorelova TN, Linde VA, Gunko VO, Krukier II, Seljutina SN. Metabolizm, transport i sostav lipidov v placente. Fundamental'nye issledovanija. 2015; 2 (26): 5832-6. Russian.

24. Stewart DJ, Monge JC. Hyperlipidemia and endothelial dysfunction. Curr Opin Lipidol. 1993; 4: 319-24.

25. Wiznitzer A, Mayer A, Novack V. Association of lipid levels during gestation with preeclampsia and gestational diabetes mellitus: a population-based study. American Journal of Obstetrics and Gynecology. 2009; 201 (5): 482.e1-482.

26. Jin W-Y, Lin S-L, Hou R-L, Xiao-Yang Chen, Ting Han, Yan Jin, et al. Associations between maternal lipid profile and pregnancy complications and perinatal outcomes: a population-based study from China. BMC Pregnancy and Childbirth. 2016; 16: 60. 
Available from: https://doi.org/10.1186/s12884-016-0852-9.

27. Oluwole AA, Adegbesan-Omilabu MA, Okunade KS. Preterm delivery and low maternal serum cholesterol level: Any

\section{Литература}

1. Sutton ALM, Harper LM, Tita ATN. Hypertensive Disorders in Pregnancy. Obstet Gynecol Clin North Am. 2018; 45 (2): 333-47.

2. Gestational Hypertension and Preeclampsia. Obstet Gynecol. 2020; 135 (6): 1492-5.

3. Nardozza LMM, Caetano ACR, Zamarian ACP, Mazzola JB, Silva CP, Marçal VMG, et al. Fetal growth restriction: current knowledge. Arch Gynecol Obstet. 2017; 295 (5): 1061-77.

4. Gaccioli F, Lager S. Placental Nutrient Transport and Intrauterine Growth Restriction. Front Physiol. 2016; 7. DOI: 10.3389/ fphys.2016.00040.

5. Benton SJ, Ly C, Vukovic S, Bainbridge SA. Andrée Gruslin award lecture: Metabolomics as an important modality to better understand preeclampsia. Placenta. 2017; 60: S32-S40.

6. Kenny LC, Broadhurst D, Brown M, Dunn WB, Redman CWG, Kell DB, et al. Detection and identification of novel metabolomic biomarkers in preeclampsia. Reprod Sci. 2008; 15 (6): 591-7.

7. Anderson, Deborah K., Liang JW and CL. Applications of Metabolomics in the Study and Management of Preeclampsia; A Review of the Literature Rachel. Metabolomics. 2017; 13 (7): 86.

8. Comhair SAA, McDunn J, Bennett C, Fettig J, Erzurum SC, Kalhan SC. Metabolomic Endotype of Asthma. J Immunol. 2015; 195 (2): 643-50.

9. Moros G, Boutsikou T, Fotakis C, lliodromiti Z, Sokou R, Katsila T, et al. Insights into intrauterine growth restriction based on maternal and umbilical cord blood metabolomics. Sci Rep. 2021; 11 (1): 1-10.

10. Parny S, Leite R, Esplin MS, Bukowski R, Zhang H, Varner M, Andrews WW, Saade GR, llekis J, Reddy UM, Huang H, Sadovsky Y, Blair IA, Biggio J; Cervicovaginal fluid proteomic analysis to identify potential biomarkers for preterm birth. Am J Obstet Gynecol. 2020; 222 (5): 493.e1-493.e13. DOI: 10.1016/j. ajog.2019.11.1252. Epub 2019 Nov 20.

11. Park S, You YA, Yun H, Choi SJ, Hwang HS, Choi SK, Lee SM, Kim YJ. Cervicovaginal fluid cytokines as predictive markers of preterm birth in symptomatic women. Obstet Gynecol Sci. 2020; 63 (4): 455-63. DOI: 10.5468/ogs.19131. Epub 2020 Jun 19.

12. AbuZar Ansari, Heeyeon Lee, Young-Ah You, Youngae Jung, Sunwha Park, Soo Min Kim, Geum-Sook Hwang, Young Ju Kim. Identification of Potential Biomarkers in the Cervicovaginal Fluid by Metabolic Profiling for Preterm Birth Metabolites. 2020; 10 (9): 349. DOI: 10.3390/metabo10090349.

13. Chambers MC, MacLean B, Burke R, Amodei D, Ruderman DL, Neumann S, et al. A cross-platform toolkit for mass spectrometry and proteomics. Nature Biotechnology. 2012; 30 (10): 918-20.

14. Pluskal T, Castillo S, Villar-Briones A, Orešič M. MZmine 2: Modular framework for processing, visualizing, and analyzing mass spectrometry-based molecular profile data. BMC Bioinformatics. correlation? Nigerian Medical Journal: Journal of the Nigeria Medical Association. 2014; 55: 5: 406-10. Available from: https:// doi.org/10.4103/0300-1652.140381.
2010; 11. DOI: 10.1186/1471-2105-11-395.

15. Koelmel JP, Kroeger NM, Ulmer CZ, Bowden JA, Patterson RE, Cochran JA, et al. LipidMatch: An automated workflow for rulebased lipid identification using untargeted high-resolution tandem mass spectrometry data. BMC Bioinformatics. 2017; 18 (1): $1-11$.

16. Liebisch G, Vizcaíno JA, Köfeler H, Trötzmüller M, Griffiths WJ, Schmitz $G$, et al. Shorthand notation for lipid structures derived from mass spectrometry. J Lipid Res. 2013; 54 (6): 1523-30.

17. R : A Language and Environment for Statistical Computing. 2018. Vienna, Austria. R Foundation for Statistical Computing.

18. R team. R Studio: Integrated Development for R. 2016.

19. Bozdogan H. Model selection and Akaike's Information Criterion (AIC): The general theory and its analytical extensions. Psychometrika. 1987; 52 (3): 345-70.

20. Kabaran S, Besler HT. Do fatty acids affect fetal programming? J Health Popul Nutr. 2015; 33: 14. DOI: 10.1186/s41043-0150018-9.PMID: 26825664.

21. Mizugishi $K$, Inoue T, Hatayama H, Bielawski J, Pierce JS, Sato $Y$, Takaori-Kondo A, Konishi I, Yamashita K. Sphingolipid pathway regulates innate immune responses at the fetomaternal interface during pregnancy. J Biol Chem. 2015; 290 (4): 2053-68. DOI: 10.1074/jbc.M114.628867. Epub 2014 Dec 11.PMID: 25505239.

22. Herrera E. Maternal-fetal transfer of lipid metabolites. In: RA Polin, WW Fox, SH Abman, editors. Fetal and Neonatal Physiology. 2004; p. 375-388.

23. Погорелова Т. Н. Линде В. А., Гунько В. О., Крукиер И. И., Селютина С. Н. Метаболизм, транспорт и состав липидов в плаценте. Фундаментальные исследования. 2015; 2 (26): 5832-6.

24. Stewart DJ, Monge JC. Hyperlipidemia and endothelial dysfunction. Curr Opin Lipidol. 1993; 4: 319-24.

25. Wiznitzer A, Mayer A, Novack $V$. Association of lipid levels during gestation with preeclampsia and gestational diabetes mellitus: a population-based study. American Journal of Obstetrics and Gynecology. 2009; 201 (5): 482.e1-482.

26. Jin W-Y, Lin S-L, Hou R-L, Xiao-Yang Chen, Ting Han, Yan Jin, et al. Associations between maternal lipid profile and pregnancy complications and perinatal outcomes: a population-based study from China. BMC Pregnancy and Childbirth. 2016; 16: 60. Available from: https://doi.org/10.1186/s12884-016-0852-9.

27. Oluwole AA, Adegbesan-Omilabu MA, Okunade KS. Preterm delivery and low maternal serum cholesterol level: Any correlation? Nigerian Medical Journal: Journal of the Nigeria Medical Association. 2014; 55: 5: 406-10. Available from: https:// doi.org/10.4103/0300-1652.140381. 